\title{
Variation of benthic macroinvertebrate communities in streams of three landscapes of South Brazilian grasslands
}

\author{
Gabriela Galeti $^{1 *}$, Bruna Maria Capitanio $^{1} \&$ Ronei Baldissera ${ }^{1}$ \\ 1. Universidade Comunitária da Região de Chapecó - UNOCHAPECÓ, Programa de Pós-Graduação em Ciências \\ Ambientais, Av. Senador Atílio Fontana, CEP 89809-000, Chapecó, SC, Brasil. gabigaleti@unochapeco.edu.br, \\ brunac@unochapeco.edu.br, roneibaldissera@unochapeco.edu.br \\ * Correspondance
}

Received 12-VI-2019. Corrected 13-XI-2019. Accepted 20-I-2020.

\begin{abstract}
Introduction: Aquatic ecosystems in southern Brazil are presently under great environmental pressure. Changes in land use result in negative impacts on the ecosystem, affecting the functioning of stream communities. Objective: To compare the benthic macroinvertebrate community richness, abundances and compositions in streams of three South Brazilian grassland landscapes and correlate community patterns with environmental and spatial variables. Methods: Fifteen streams along riparian forests were selected in three landscapes (mean geographical distance of $285.1 \mathrm{~km}$ ) inserted in the Paraná and Uruguai river basins. Of the three landscapes, two are inserted in conservation units (State Park of Guartelá and Palmas Wildlife Refuge). Invertebrates were collected in 20 kick net points along $150 \mathrm{~m}$ of the streams between June and November 2015. Invertebrates were sorted in the laboratory with three sieves and were identified to the lowest taxonomic level possible. The taxa were classified in functional feeding groups of shredders/detritivores, predators, scrapers, collectors/filters and gatherers/collectors. For each stream, we measured the environmental variables width and velocity, $\mathrm{pH}$, dissolved oxygen, and temperature; and the relative cover of forest, grassland, plantation and silviculture in the catchments. Results: We found a total of 1058 individuals, divided in 53 morphospecies and 34 families. Lower abundance of benthic macroinvertebrates was found in the northernmost landscape with higher temperature, and forest in the catchment. These streams were described mainly by predator groups, while streams inserted in the other two landscapes showed a more diverse guild composition of shredders/detritivores, gatherers/collectors, collectors/filterers, and scrapers. Geographical distance was the main factor influencing differences in community compositions among landscapes. Conclusions: Lower abundance of the northernmost landscape may be explained by (i) the low habitat heterogeneity due to dominance of sandy substrates, and by (ii) the anthropogenic land use of agriculture and extensive cattle breeding in the region that is ongoing and started before the creation of the conservation unit. Additionally, composition of macroinvertebrates may be correlated with environmental differences among landscapes that, in turn, are related to the geographical distance. Therefore, macroinvertebrate community responses may reflect different biota biogeographical histories that can also be associated with historical land use practices.
\end{abstract}

Key words: land use, functional feeding groups, abiotic variables, sandy substrate, freshwater diversity, agriculture.

Galeti, G., Capitanio, B. M. \& Baldissera, R. (2020). Variation of benthic macroinvertebrate communities in streams of three landscapes of South Brazilian grasslands. Revista de Biología Tropical, 68(1), 108-121.

The study of biodiversity variation between geographic regions is a key issue for disciplines like ecology, zoology, conservation, and management (Tuomisto, 2010;
Anderson et al., 2010). Here, we are especially interested in variation of benthic macroinvertebrate communities associated with different spatial scales. These animals possess desirable 
attributes for studying such variation. They are highly diverse and distributed in most freshwater stream habitats under different environmental characteristics (Hussain \& Pandit, 2012), reflecting the streams' health. The taxon is essential for energy flux, nutrient cycling and organic matter degradation in lentic and lotic environments, being a central component of freshwater ecosystems (Whiles \& Wallace, 1997; Allan \& Castillo, 2007). Organisms are easily collected due to their high abundance, and the community patterns can rapidly change in response to biotic and/or to abiotic characteristics, like habitat heterogeneity and water quality, and at local, regional or geographic scales (Brosse, Arbuckle, \& Townsend, 2003; Heino, Muotka, \& Paavola, 2003; Hepp \& Santos, 2009; Rezende, Santos, Henke-Oliveira, \& Gonçalves Jr, 2014).

At local scale, stream's sediment composition, allochthonous material, and canopy openness are the main variables controlling diversity of benthic macroinvertebrate communities (Harper, Mekotova, Hulme, White, \& Hall, 1997). Natural topographic characteristics can also affect invertebrate diversity if fine sediments are predominant in the stream (Vannote, Minshall, Cummins, Sedell, \& Cushing, 1980). Physical, chemical and structural features are also important for aquatic life; for instance, dissolved oxygen, electric conductivity, alkalinity, and temperature are known to influence invertebrate occurrence and distribution (Melo, 2009; Rezende et al., 2014). Additionally, the communities' composition changes and the richness increase from the headwaters to the base level in response mainly to stream's width, depth, temperature and production/respiration ratio (Vannote et al., 1980; Jacobsen, 2004; Baptista et al., 2014).

Widespread distribution of benthic macroinvertebrates is possible because they have evolved a diverse spectrum of morphological and behavioral mechanisms for exploiting foods, which are used to classify their functional role in aquatic ecosystems (Cummins \& Klug, 1979; Merritt \& Cummins, 2006; Hamada, Nessimian, \& Querino, 2014). Feeding groups or guilds of benthic macroinvertebrates are defined as sets of taxa exploring the same class of food resources in a similar manner (Merrit, Cummins, \& Berg, 2008). Differences in the distribution of feeding groups in streams of a region may indicate the integrity of aquatic system (Fu et al., 2015; Castro, Dolédec, \& Callisto, 2017). Therefore, studying benthic macroinvertebrate feeding group distributions in aquatic ecosystems is a useful tool for management and conservation (Callisto \& Esteves, 1998; Callisto, Moreno, \& Barbosa, 2000; Merritt, Fenoglio, \& Cummins, 2016; Echelpoel et al., 2018).

Environmental assessment of aquatic invertebrate responses to anthropogenic disturbance helps to understand which factors drive community structure changes (Hepp et al., 2016; Castro, Dolédec, \& Callisto, 2018; Ongaratto, Loureiro, Restello, \& Hepp, 2018). Aquatic ecosystems in subtropical Brazil are presently under intense environmental pressure due to riparian vegetation suppression and allochthonous inputs from watercourses' surroundings (Ferreira, Cyrino, Duarte-Neto, \& Martinelli, 2012). Inserted in this climatic region, South Brazilian grasslands encompass regions of Pampa biome extending from the southernmost part of Brazil to Uruguai and Argentina, and grasslands at highlands in Atlantic Forest biome of South Brazil (Overbeck et al., 2009). The grasslands guarantee key environmental services like hydrological resource conservation and biodiversity (Pillar, Müller, Castilhos, \& Jacques, 2009). In the last decades, the conversion of grasslands to agriculture, silviculture, and pasture have reduced the natural grassland vegetation area by $50 \%$ (Cordeiro \& Hasenack, 2009). These anthropogenic activities impact the aquatic ecosystems, leading to multiple physicalchemical and structural changes in the water courses, affecting taxa occurrence and distribution (Utz, Hilderbrand, \& Boward, 2009). Land use effects on freshwater communities are complex and scale dependent (Allan, 2004). At landscape scale of streams' catchments, human activities like agriculture can increase sediment 
and nutrient load, as well as flood frequency, and decrease groundwater recharge (Carpenter, Stanley, \& Zanden, 2011). At local scale, replacement of native vegetation by human activities may, for instance, change input of solar radiation, thus affecting primary productivity (Burrell et al., 2013).

Based on the responses of aquatic communities to local and landscape environmental features, our objective was to compare the benthic macroinvertebrate communities in streams of three South Brazilian grassland landscapes. To do so, we measured communities' richness, abundance and feeding group compositions, and assessed the role of variables associated with local (water chemistry and riverbed structure) and landscape (catchment land use) scales, and with geographical distance as drivers of macroinvertebrate community variations. We hypothesized that streams with more preserved habitat conditions linked to less disturbance in surrounding land have higher taxonomic richness and more diverse feeding groups.

\section{MATERIALS AND METHODS}

Study area: We performed the study in three South Brazilian grassland (Campos) landscapes (Fig. 1). The region of South Brazilian grasslands is characterized by mosaics of shrubland and forest patches embedded in a matrix of natural grassland. Historically, the grasslands were used for livestock, mainly sheep and cattle for beef production (Overbeck et al., 2007). Recently, a large part of these natural grasslands was converted to croplands, mainly wheat, soybean, rice and maize. The landscapes were chosen based on the presence of at least $50 \%$ of natural grassland cover after satellite imagery inspection in Google Earth and local validation. Landscapes are inserted in two large river basins: (i) Paraná river - city of Palmas
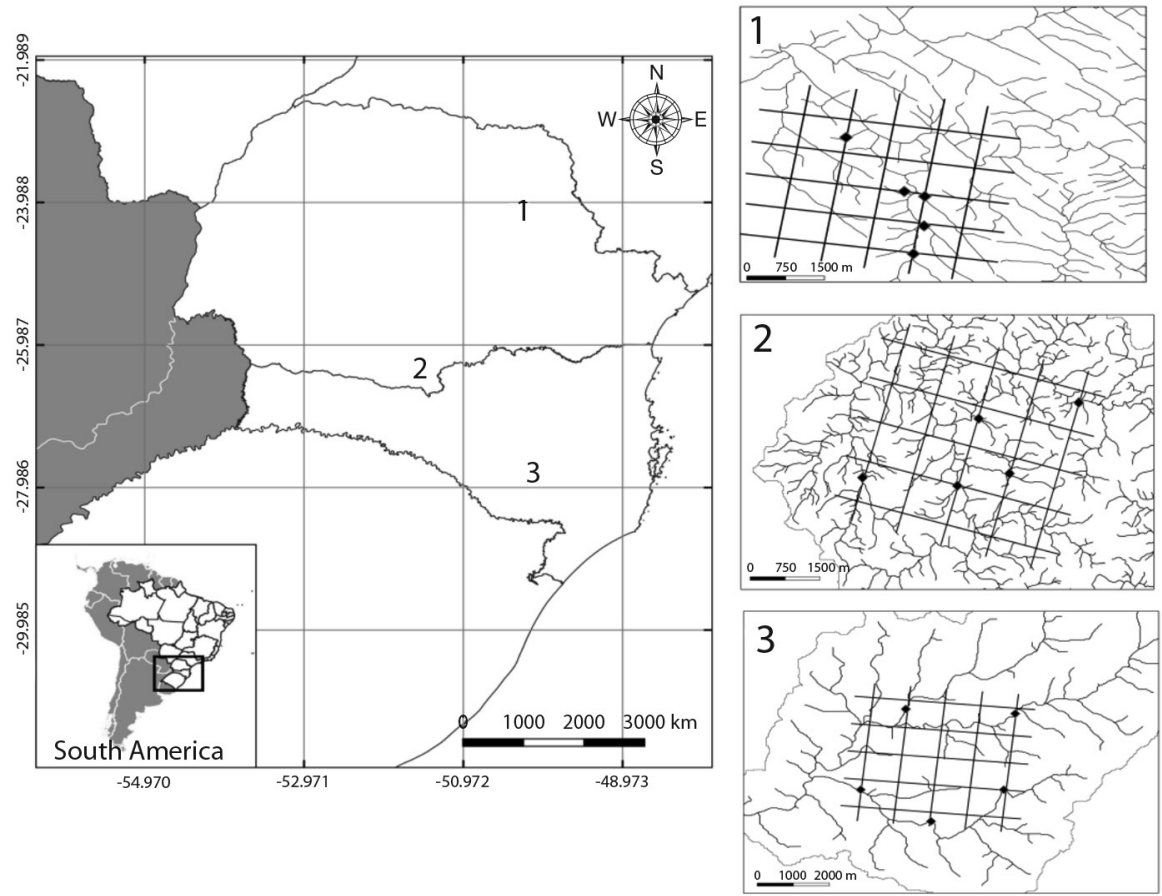

Fig. 1. Location of the south Brazilian region under study in South America. 1 - River basin of Tibagi/PR showing the grid of the $25 \mathrm{~km}^{2}$ landscape and the location of the five selected streams. 2 - River basin of Palmas/PR showing the grid of the $25 \mathrm{~km}^{2}$ landscape and the location of the five selected streams. 3 - River basin of Painel $/ \mathrm{SC}$ showing the grid of the $25 \mathrm{~km}^{2}$ landscape and the location of the five selected streams. 
(UTM 22 J $437612.67 \mathrm{~m} \mathrm{E}-7065595.88 \mathrm{~m}$ S; 1115 m.a.s.l.) and city of Tibagi (UTM 22 J $575509.83 \mathrm{~m} \mathrm{E}-7282637.15 \mathrm{~m} \mathrm{~S} ; 748$ m.a.s.l.); and (ii) Uruguai river - city of Painel (UTM 22 J $580844.12 \mathrm{~m} \mathrm{E}-6901796.10 \mathrm{~m}$ S; 1144 m.a.s.l.). In Palmas (PAL), the collections were carried out at the Campos de Palmas Wildlife Refuge, a full protection unit located in the South-central region of Paraná state. In Tibagi (TIB), the collections were carried out in the State Park of Guartelá full protection unit in the central-eastern portion of the state of Paraná. Painel (PAI) landscape is not part of a protection unit. Surroundings of streams in PAI are mainly composed of areas of natural grasslands typically used for cattle breeding and fewer areas of plantations and silviculture (Table 1). Silviculture area in the streams' catchments was larger in PAL landscape, and TIB showed larger area of plantations (Table 1). The stream sediments in PAI and PAL are composed mostly by boulders ( $>$ $256 \mathrm{~mm}$ ), gravels $(4-64 \mathrm{~mm})$, and a mixture of sands (0.06 - $1.2 \mathrm{~mm}$ ) (Wentworth, 1922). Streams also have dry leaves, branches and twigs characterizing a heterogeneous habitat. On the other hand, sediments in TIB streams are dominated by sands, characterizing a less heterogeneous habitat. All streams had riparian forest on both margins.

Invertebrate sampling: We surveyed 15 streams $\left(2^{\text {nd }}\right.$ to $4^{\text {th }}$ order $)$, five in each landscape (Table 1). Each stream was sampled once. Inside each stream we chose an easy access point to start the sampling and go through 150 $\mathrm{m}$ downstream. Along that distance, we collected benthic fauna in 20 backwater points. At each point, the researcher kicked 10 times the sediment inside a sweeping net, method called kick and sweep net $(K \& S)$, which is routinely used for assessing biodiversity (Tubic et al., 2017). The sediments were placed inside plastic bags and milk pails with absolute alcohol. Streams were sampled between June and November 2015.

In the laboratory, the sediments were washed in 1.0-, 2.0- and 3.0-mm-mesh sieves.
The invertebrates from the 3.0-mm-mesh sieve were sorted by visual inspection. The material of the other two sieves were fixed in 70 $\%$ alcohol. The great amount of sandy sediments in each sample made extensive sorting of macroinvertebrates unviable. Therefore, we used the collector's curve asymptote criterion to set the maximum number of samples of sandy sediments from each river. We started arbitrarily with a sample of $7.5 \mathrm{~g}$ of sediments and counted the number of morphotypes. We repeated the process until the collector's curve reached the asymptote for each river (Magurran, 2013). After 10 samples (75 g) all streams' curves reached the asymptote and we stopped the macroinvertebrate sorting. Invertebrates were identified to the lowest taxonomic level according to Hamada, Nessimian, and Querino (2014), Dominguez and Fernandez (2009) and Souza, Costa, and Oldrini (2007). The taxa were classified in functional feeding groups of (i) shredders/detritivores - which consume leaf litter or other coarse particulate organic matter, (ii) predators - which feed on other consumers, (iii) scrapers - which consume algae and associated material, (iv) collectors/ filters - which collect fine particulate organic matter from the water column using a variety of filters, and (v) gatherers/collectors - which collect fine particulate organic matter from the stream bottom (Merrit, Cummins, \& Berg, 2008; Hamada et al., 2014).

Environmental variables: We measured eight environmental variables inside and in the surroundings of the catchments (Table 1). Locally, variables were mean water velocity (three measurements in the beginning, middle and final points of the $150 \mathrm{~m}$ ), mean stream's width (same three points), $\mathrm{pH}$, dissolved oxygen, and water temperature. We set a $500 \mathrm{~m}$ radius buffer initiating in the starting point of macroinvertebrate sampling and, inside each buffer, we measured the relative cover of forests, grasslands, plantations and silviculture (in ha) in Google Earth.

Data analyses: We performed a principal component analysis (PCA) with all 


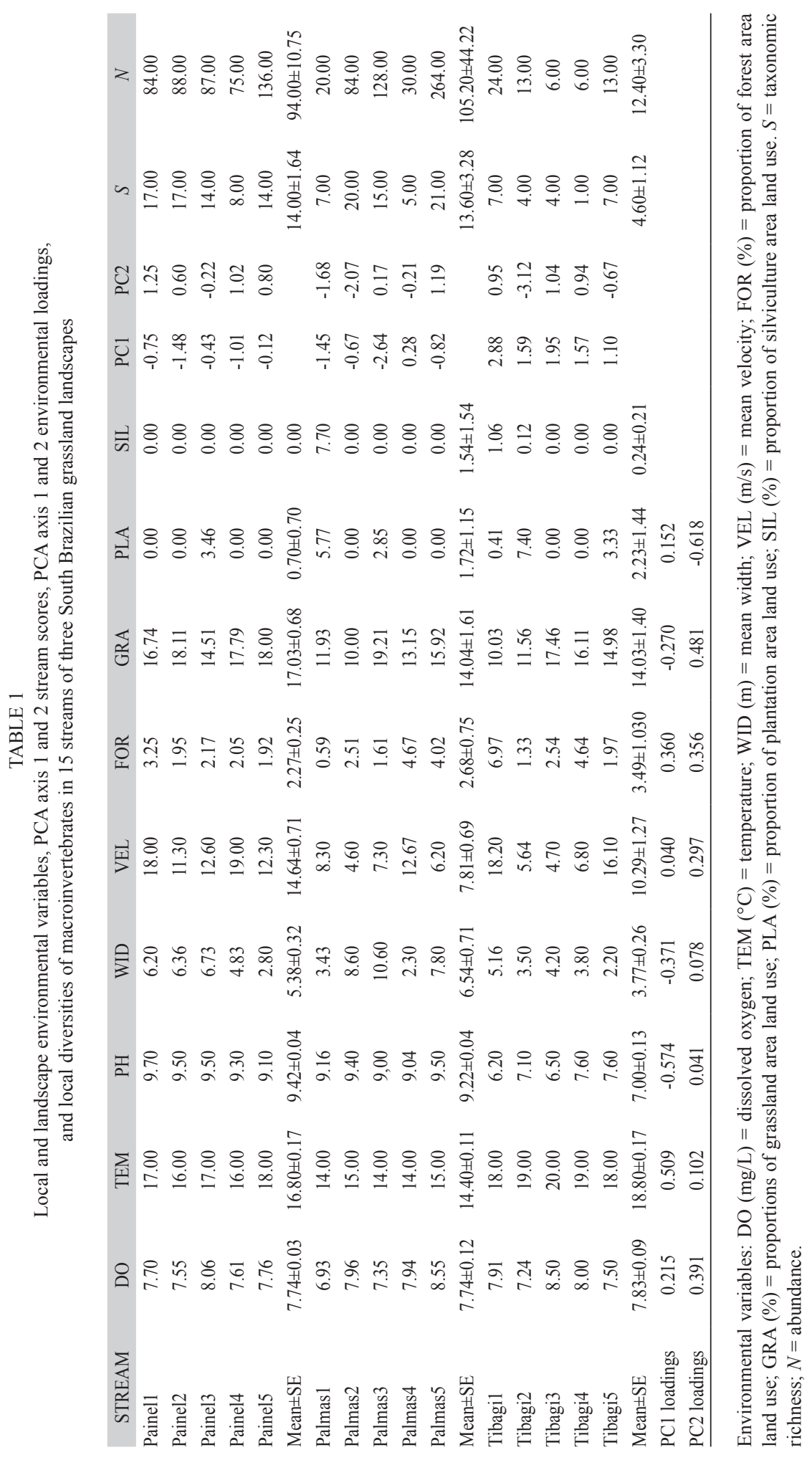


environmental variables to characterize the three landscapes. We transformed all variables to zero mean and unit variance before analysis. We used the first and second principal components - PC1 and PC2 of PCA as predictor variables of macroinvertebrate community responses. Richness (number of taxa) and abundance (number of individuals) of macroinvertebrates were highly correlated $(\mathrm{R}=0.812)$. It means that any analysis of possible correlations between environmental variables and macroinvertebrate richness would be biased by abundance. Therefore, we performed a simple linear regression with abundance (X) and richness (Y) and used the vector of residuals as the new richness of macroinvertebrates. To assess whether richness and abundance differed among landscapes, we used two permutational analyses of variance (Wheeler \& Torchiano, 2016). The test criterion of permutational ANOVAs is the sum of squares (SS). To identify which predictor variables affected the response of richness and abundance, we performed two multiple linear regression with sequential entering of predictor variables, first $\mathrm{PC} 1$ and then PC2. Abundance of macroinvertebrates was log transformed before multiple regression to meet normality assumptions.

We explored the similarity of benthic macroinvertebrate feeding group compositions among streams with a non-metric dimensional scaling ordination (NMDS) based on BrayCurtis dissimilarity of feeding groups abundance data. We performed a permutational multivariate analysis of variance (PERMANOVA) after NMDS to check for differences among landscapes based on the feeding group compositions. Additionally, we tested the effect of space and environment on feeding group compositions by means of partial Mantel correlation tests using the dissimilarity/ distance matrices. First, we decomposed the variation explained by space and environment into community composition variation among landscapes. Second, we analyzed within landscape composition variations. Analyses were performed in RStudio v. 3.5.1 (R Core Team, 2016).

\section{RESULTS}

A total of 1058 benthic macroinvertebrates were collected divided in 53 taxa (Digital Appendix). Bivalvia sp. $(\mathrm{N}=363)$ was the most abundant taxon in all streams, followed by Aegla sp. $(\mathrm{N}=175)$ and Lymnaeidae sp. $(\mathrm{N}=147)$. In PAL Bivalvia sp. was the most abundant taxon $(\mathrm{N}=306)$, whereas in PAI it was Lymnaeidae $(\mathrm{N}=147)$ and Aegla sp. ( $\mathrm{N}$ $=133$ ). Finally, the streams of TIB showed greater abundance of Limnocoris sp. $(\mathrm{N}=21)$. Abundance was significantly different among landscapes ( $\mathrm{SS}=25660 ; \mathrm{P}=0.038$; d.f. $=2.12$ ), however the residual richness was not different among landscapes ( $\mathrm{SS}=678.9 ; \mathrm{P}=0.888$; d.f. $=2.12$ ). TIB streams showed nearly one third lower mean abundance and around $10 \%$ lower mean richness than streams of PAL and PAI (Table 1). Abundance responded significantly to PCA 1 predictor $\left(\mathrm{R}^{2}=0.568, \mathrm{P}=0.006\right)$ (Fig. 2). Residual richness did not respond to environmental variables $\left(\mathrm{R}^{2}=0.168, \mathrm{P}=0.330\right)$.

The first two axes of PCA explained $51.61 \%$ of total variation in the matrix of environmental variables. Table 1 shows stream

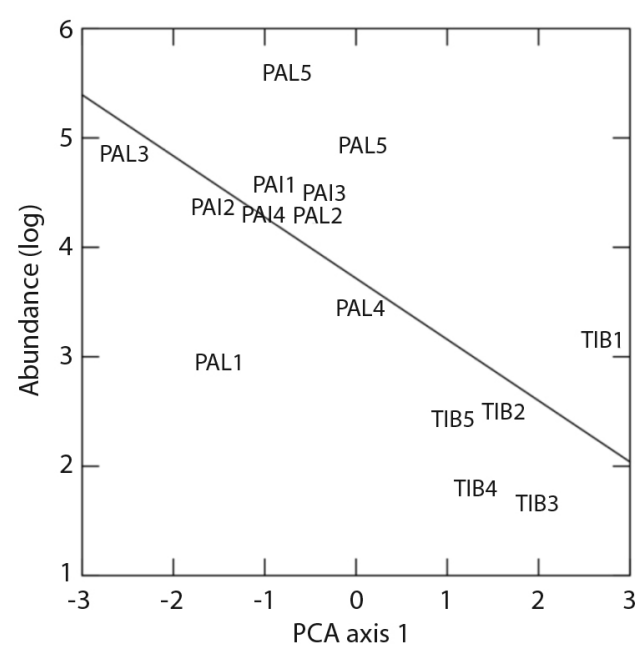

Fig. 2. Relationship between abundance (log transformed) of benthic macroinvertebrates and PCA axis 1 of environmental variables. Data collected in 15 streams of three landscapes in South Brazilian grasslands in Winter and Spring 2015. PAL $=$ Palmas, PAI $=$ Painel, $\mathrm{TIB}=$ Tibagi. Response model is Abundance $=3.72-0.60 *$ PCA1 . 


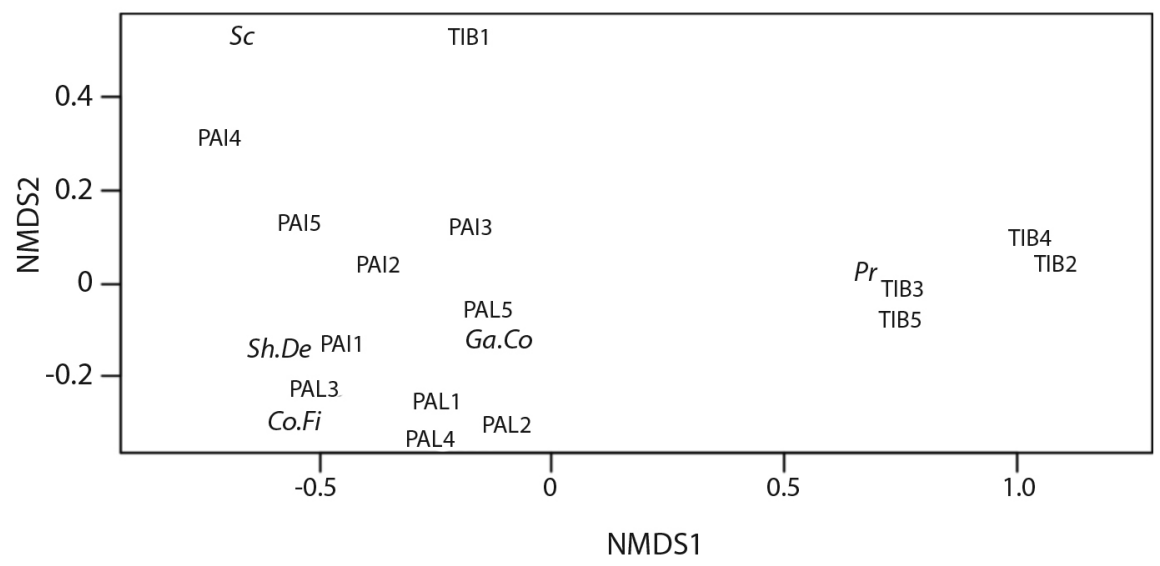

Fig. 3. First and second NMDS axes based on Bray-Curtis dissimilarity distances between feeding group abundances in 15 streams of three landscapes in South Brazilian grasslands. PAI = Painel, PAL $=$ Palmas, TIB $=$ Tibagi. Feeding groups are $\mathrm{Co} . \mathrm{Fi}=$ collectors/filterers, $\mathrm{Ga} . \mathrm{Co}=$ gatherers/collectors, $S c=$ scrapers, $S h . D e=$ shredders/detritivores, $\operatorname{Pr}=$ predators. Stress of NMDS $=0.059$.

scores and variable loadings in the first and second PCA axes. The first axis varied from TIB streams to PAI and PAL streams. TIB was characterized by higher temperature and area of forest in the catchment and lower $\mathrm{pH}$ and mean width. PAI and PAL were characterized by lower temperature and area of forest and higher $\mathrm{pH}$ and width. Second axis varied from two PAL streams with higher plantation area in the catchment to all the rest of PAL and PAI streams associated with higher grassland area and water velocity.

Regarding the compositions of functional feeding groups, the main variation was associated with first axis of ordination (Fig. 3), which divided the streams of TIB from the ones in PAI and PAL. Results of PERMANOVA showed that the three landscapes were different regarding macroinvertebrate feeding group compositions $\left(\mathrm{F}_{2,14}=7.45 ; \mathrm{P}=0.001\right)$. TIB streams had more predators like Hemiptera and Odonata. PAI and PAL streams showed more diverse communities of shredders/ detritivores, gatherers/collectors, collectors/ filterers, and scrapers (Fig. 3). Additionally, along the second axis of NMDS, PAI streams were better described by the abundance of scrapers, compared to PAL streams (Fig. 3). PAL streams showed higher abundance of collectors/filterers Bivalvia, Hydropsychidae and Simuliidae, and the gatherers/collectors Elmidae. PAI streams also had higher diversity compared to TIB and showed the presence of the shredder/detritivore Aeglidae and the gatherers/collectors Ceratopogonidae.

Among landscapes, partial Mantel tests showed that the highest correlation was between feeding guild composition and space $\left(\mathrm{R}_{\mathrm{M}}=\right.$ 0.67; $\mathrm{P}=0.001)$, compared to environment $\left(\mathrm{R}_{\mathrm{M}}=0.38 ; \mathrm{P}=0.002\right)$. Additionally, space and environment were significantly correlated $\left(R_{M}\right.$ $=0.32 ; \mathrm{P}=0.001)$. It means that environmental variation was linked to geographical distance, which is expected, given the extent region of the study. Within each landscape, the dissimilarity in macroinvertebrate compositions in TIB were correlated with the environmental distance $\left(\mathrm{R}_{\mathrm{M}}=0.79 ; \mathrm{P}=0.025\right)$.

\section{DISCUSSION}

The lack of communities' local responses to environmental variables measured at higher scale does not immediately translate into a lack of streams' surroundings effect since high unexplained variation is common in many ecological studies, partly due to missing variables in the analyses (Genner et al., 2004; Hepp, 
Landeiro, \& Melo, 2012). On the other hand, although the landscapes are predominantly grassy habitats, we could observe marked differences mainly in the taxonomic and functional feeding groups of streams in the northernmost TIB landscape.

Landscapes studied here encompass a wide geographical scale. Latitudinal gradients in aquatic invertebrates are ambiguous, so patterns of variation are study-dependent. Therefore, local environment features can supposedly override historical and climatic influences on diversity (Hillebrand, 2004; Heino, 2009). Hence, the type of substrate could partially explain the lower diversity found in TIB streams. Texture, compaction, and grain size can affect the composition and abundance of benthic macroinvertebrates (Nakamura \& Kikuchi, 1996; Fidelis, Nessimian, \& Hamada, 2008; Baptista et al., 2014). Sandy soils are characterized by low heterogeneity and availability of physical habitats (Allan, 2004). Additionally, these habitats are subjected to disturbances due to the stream's current. Despite the greater coverage of riparian vegetation in TIB, allochthonous materials are drifted and not deposited in the stream bed due to the absence of larger substrates. Contrasting features were found in PAL and PAI, leading to a more heterogeneous environment. The occurrence of pebbles and coarse fractions of substrate increases the number of shelters (Bücker, Sondermann, Frede, \& Breuer, 2010; Jun et al., 2011; Hepp et al., 2012; Rezende et al., 2014), translating into more taxonomic and functional diversity. TIB water temperature was higher than in PAI and PAL, which may be related to the lower altitude of this landscape and the sampling period at the beginning of the warmer months of the year.

TIB benthic macroinvertebrate diversity was different from those of the other landscapes. The presence of predators was represented particularly by Gomphidae (Odonata) and Naucoridae (Hemiptera). The presence of Gomphidae may be associated with its fossorial attribute, which enables the organisms to use inorganic substrates, such as sand and gravel (Assis, Carvalho, \& Nessimian, 2004; Worthen, Gregory, Felten, \& Hutton, 2004; Worthen \& Horaceh, 2015). Hemiptera are common predators in lentic and lotic habitats, with good swimming capacity and adapted to various habitats, including sand sites, which may explain their presence in TIB (McCafferty, 1981; Hamada et al., 2014; Reynoso-Velasco $\&$ Sites, 2019). In addition to these taxa, we recorded the presence of the family Odontoceridae, known for the construction of tubular shelters made of grains of sand glued with silk, attribute that facilitates the occupation of different niches compared to other species of caddisflies. Moreover, this taxon could search more actively for food (Guevara, Reinoso, \& Villa, 2005; Vásquez-Ramos, Guevara-Cardona, \& Reinoso-Florez, 2014) in the sandy habitats found in TIB streams.

Despite the high abundance of scrapers such as Lymnaidae in PAI streams, we also found representants of the EPT group (Ephemeroptera, Plecoptera, and Trichoptera), which are the first to disappear in highly disturbed streams due to their sensitivity to pollution and thus generally considered bioindicators of good water conditions (Barbola et al., 2011; Júnior, Conceição, Lobo, Santos, \& Sardinha, 2019). Another sensitive taxon that appeared in all PAI and PAL streams was Aegla sp. Aeglids live preferentially in well-oxygenated and clean water habitats (Bond-Buckup \& Buckup, 1994; Dalosto \& Santos, 2011; Santos et al., 2017). On the other hand, the presence of Oligochaetes in PAL landscape could be signaling the beginning of water deterioration, because these organisms can survive under low dissolved oxygen conditions (Piedras et al., 2006, Rosa, Rodrigues, Oliveira, \& Alves, 2014). Moreover, changes in water quality associated with organic contamination lead to the increase of suspended particles, favoring filter-collector organisms (Bivalvia) (Feio \& Dolédec, 2012).

Different benthic macroinvertebrate functional groups explore different resources and are influenced by habitat features, food, and refuge availability (Callisto, Moreno, \& Barbosa, 2000; Benstead \& Pringle, 2004). 
Therefore, the more variation in these environmental features the greater the diversity and the resistance of benthic macroinvertebrate community to disturbance (Hawkins \& MacMahon, 1989). Thus, there could be two different but not excluding forces driving the overall lower diversity of TIB streams. First, the low heterogeneity is driven by the presence of one dominant sandy substrate. Second, the anthropogenic land use of agriculture and extensive cattle breeding in the region that is ongoing and started before the creation of the conservation unit.

In Palmas landscape, the land use alterations also started before conservation unit creation, extending to today. So, these past environmental alterations could have led to riparian forest and landscape structural changes, factors that affect the benthic macroinvertebrate richness and composition (Hepp \& Santos, 2009; Sensolo, Hepp, Decian, \& Restello, 2012; Hepp et al., 2016). The replacement of specialist organisms by generalists occurs as a response to changes in land use (Petsch, 2016; Castro et al., 2018). Additionally, the spatial pattern of distribution of the populations depends on factors reflecting the spatial organization of habitat patches (Vinatier, Tixier, Duyck, \& Lescourret, 2011). Therefore, high variation in the local context of streams could lead to high dissimilarity of taxonomic and functional compositions within the landscapes.

There was a marked structural difference among the three landscapes at local and landscape scales. Studies conducted with different organisms have shown that both local environmental conditions and geographical distances shape community structure (Heino et al., 2010; Santos, Silva, Branco, \& Huszar, 2015; Monteiro do Amaral, De Almeida Gonçalves, Da Silveira, \& Gama Alves, 2019). At regional level the observed variations in aquatic biota were partially associated with landscape changes, but the main driving force was geographical distance. Campos in PAL and TIB landscapes were more fragmented compared to PAI. The PAI landscape, despite not being included in a protected area, had greater coverage of natural grasslands, which can be related to the traditional grazing activity (e.g. cattle, horses) that was almost exclusive in PAI landscape. Given this condition, our initial hypothesis that diversity would be higher in more conserved areas was partially corroborated.

Intensive agriculture can change soil physical and chemical properties, compaction, erosion and water regime (Vieira \& Overbeck, 2015). However, other environmental variables should be analyzed (e.g. heavy metals, phosphorus, nitrogen) to better understand the diversity patterns found in the three Campos landscapes, mainly in regions of agriculture and livestock farming and silviculture practices, where the water courses are subjected to pesticide and fertilizer residues from the land. Besides, benthic invertebrate communities can respond to other unmeasured variables either at local or at landscape scales. We believe it is important to deepen the studies on natural grassland regions, a historically neglected biome in Brazil (Overbeck et al., 2009), to assess the conservation status of landscapes and to understand the distribution of aquatic diversity at local, landscape and geographical scales. The results point to the need for discussions about public policies addressing water conservation and management, which should include a mixed collegiate body in Advisory Councils (e.g. community, researchers, authorities). These actions may focus on discussing the role of the grassland landscapes studied here. Although the streams are in protected areas, they still suffer from anthropic activities, which can impact the local and regional benthic macroinvertebrate diversity.

Ethical statement: authors declare that they all agree with this publication and made significant contributions; that there is no conflict of interest of any kind; and that we followed all pertinent ethical and legal procedures and requirements. All financial sources are fully and clearly stated in the acknowledgements section. A signed document has been filed in the journal archives. 


\section{ACKNOWLEDGMENTS}

Gabriela Galeti received a research fellowship from Fundo de Apoio à Manutenção e ao Desenvolvimento da Educação Superior - FUMDES of Santa Catarina Government. The authors thank Veluma I. M. de Bastiani and Diego Costa for field assistance; Walkiery Raimundi and Rosicleia Pansera for helping in the sorting of invertebrates in the laboratory and Erikcsen A. Raimundi for helping in some identifications.

\section{RESUMEN}

Variación de comunidades de macroinvertebrados bentónicos en arroyos de tres paisajes de pastizales del sur de Brasil. Introducción: Los ecosistemas acuáticos en el sur de Brasil están actualmente bajo gran presión ambiental. Cambios en el uso de la tierra pueden tener impactos negativos en el ecosistema que afectan el funcionamiento de las comunidades de arroyos. Objetivo: Comparar la riqueza, abundancia y las composiciones de macroinvertebrados bentónicos en arroyos de tres paisajes de pastizales del sur de Brasil, y correlacionar los modelos patrones de comunidad con variables ambientales y espaciales. Metodología: Quince arroyos a lo largo de los bosques ribereños fueron seleccionados en tres paisajes (distancia geográfica media de $285.1 \mathrm{~km}$ ) insertados en las cuencas fluviales de Paraná y Uruguai. De los tres paisajes, dos están insertados en unidades de conservación (Parque Estatal de Guartelá y Refugio de Vida Silvestre de Palmas). Los invertebrados fueron recolectados en 20 puntos con una red a lo largo de $150 \mathrm{~m}$ de las corrientes entre junio y noviembre 2015. En el 2016, fueron clasificados en el laboratorio, con tres tamices de mallas, identificándolos al nivel taxonómico más bajo posible. Así, los taxones se clasificaron en grupos funcionales alimentícios: trituradores/detritívoros, depredadores, raspadores, colectores/ filtradores y colectores/recolectores. En cada arroyo fueron medidas las variables ambientales: anchura, velocidad, $\mathrm{pH}$, oxígeno disuelto y temperatura; en las cuencas, la cubierta relativa de bosques, pastizales, plantaciones y silvicultura. Resultados: Encontramos un total de 1058 individuos, divididos en 53 morfoespecies y 34 familias. Se encontró una menor abundancia de macroinvertebrados bentónicos en el paisaje más septentrional con mayor temperatura, y bosques en la cuenca. Esos arroyos fueron descritos principalmente por grupos de depredadores, mientras que los arroyos insertados en los otros dos paisajes mostraron una composición más diversa de trituradores/detritívoros, colectores/recolectores, colectores/filtradores y raspadores. La distancia geográfica fue el principal factor que influyó en las diferencias de las composiciones comunitarias entre los paisajes. Conclusiones: La menor abundancia encontrada en el paisaje más septentrional puede explicarse por (i) la baja heterogeneidad constatada en el hábitat, debido al dominio de los sustratos arenosos, y por (ii) el uso antropogénico de la tierra: la agricultura y la cría extensiva de ganado en la región que está en curso, la cual comenzó antes de la creación de la unidad de conservación. Además, la composición de los macroinvertebrados puede estar correlacionada con diferencias ambientales entre paisajes que, a su vez, están relacionadas con la distancia geográfica. Por lo tanto, las respuestas comunitarias de los macroinvertebrados pueden reflejar diferentes historias biogeográficas de biotas que también pueden estar asociadas a prácticas históricas de uso de la tierra.

Palabras clave: uso de la tierra, grupos funcionales alimentarios, variables abióticas, substrato arenoso, diversidad dulceacuícola, agricultura.

\section{REFERENCES}

Allan, J. D. (2004). Landscapes and riverscapes: the influence of land use on stream ecosystems. Annual Review of Ecology Evolution and Systematics, 35(1), 257-284.

Allan, J. D., \& Castillo, M. M. (2007). Stream Ecology: Structure and Function of Running Waters. Netherlands: Springer.

Anderson, M. J., Crist, T. O., Chase, J. M., Vellend, M., Inouye, B. D., Freestone, A. L., ... Swenson, N. G. (2010). Navigating the multiple meanings of $\beta$ diversity: a roadmap for the practicing ecologist. Ecology Letters, 14(1), 19-28. DOI: 10.1111/j.1461-0248.2010.01552.x

Assis, J. C. F., Carvalho, A. L., \& Nessimian, J. L. (2004). Composição e preferência por microhábitat de imaturos de Odonata (Insecta) em um trecho de baixada do Rio Ubatiba, Maricá-RJ, Brasil. Revista Brasileira de Entomologia, 48(2), 273-282. DOI: 10.1590/ S0085-56262004000200017

Baptista, V. A., Antunes, M. B., Martello, A. R., Figueiredo, N. S. B., Amaral, A. M. B., Secretti, E., \& Braun, B. (2014). Influência de fatores ambientais na distribuição de famílias de insetos aquáticos em rios no sul do Brasil. Ambiente \& Sociedade, 17(3), 155-176. DOI: $10.1590 / \mathrm{S} 1414-753 \mathrm{X} 2014000300010$

Barbola, I. F., Moraes, M. F. P. G., Anazawa, T. M., Nascimento, E. A., Sepka, E. R., Polegatto, C. M., ... Schühli, G. S. (2011). Avaliação da comunidade de macroinvertebrados aquáticos como ferramenta para o monitoramento de um reservatório na bacia do rio Pitangui, Paraná, Brasil. Iheringia, Série Zoologia, 101(1-2), 15-23. DOI: 10.1590/ S0073-47212011000100002

Benstead, J. P., \& Pringle, C. M. (2004). Deforestation alters the resource base and biomass of endemic stream 
insects in eastern Madagascar. Freshwater Biology, 49, 490-501. DOI: 10.1111/j.1365-2427.2004.01203.x

Bond-Buckup, G., \& Buckup, L. (1994). A família Aeglidae (Crustacea, Decapoda, Anomura), Arquivos de Zoologia, São Paulo, 32(4), 159-346. DOI: 10.11606/ issn.2176-7793.v32i4p159-346

Brosse, S., Arbuckle, C. J., \&, Townsend, C. R. (2003). Habitat scale and biodiversity: influence of catchment, stream reach and bedform scales on local invertebrate diversity. Biodiversity and Conservation, 12, 2057- 2075. DOI: 10.1023/A:1024107915183

Bücker, A., Sondermann, M., Frede, H. G., \& Breuer, L. (2010). The influence of land-use on macroinvertebrate communities in montane tropical streams - a case study from Ecuador. Fundamental and Applied Limnology, 177(4), 267-282. DOI: $10.1127 / 1863-9135 / 2010 / 0177-0267$

Burrell, T. K, O’Brien, J. M., Graham, S. E., Simon, K. S., Harding, J. S., \& McIntosh, A. R. (2013). Riparian shading mitigates stream eutrophication in agricultural catchments. Freshwater Science, 33(1), 73-84. DOI: $10.1086 / 674180$

Callisto, M., \& Esteves, F. A. (1998). Categorização funcional dos macroinvertebrados bentônicos em quatro ecossistemas lóticos sob influência das atividades de uma mineração de bauxita na Amazônia central (Brasil). In J. L. Nessimian \& A. L. Carvalho (Eds.), Ecologia de Insetos Aquáticos (pp. 223-234). Rio de Janeiro: PPGE-UFRJ.

Callisto, M., Moreno, P., \& Barbosa, F. A. R. (2000). Diversidade de habitats e grupos tróficos funcionais na Serra do Cipó, sudeste do Brasil. Revista Brasileira de Biologia, 61(2), 259-266. DOI: 10.1590/ S0034-71082001000200008

Carpenter, S. R., Stanley, E. H., \& Zanden, M. J. V. (2011). State of the world's freshwater ecosystems: physical, chemical, and biological changes. Annual Review of Environment and Resources, 36, 75-99. DOI: 10.1146/annurev-environ-021810-094524

Castro, D. M. P., Dolédec, S., \& Callisto, M. (2017). Landscape variables influence taxonomic and trait composition of insect assemblages in Neotropical savanna streams. Freshwater Biology, 62(8), 14721486. DOI: $10.1111 /$ fwb.12961

Castro, D. M. P., Dolédec, S., \& Callisto, M. (2018). Land cover disturbance homogenizes aquatic insect functional structure in neotropical savanna streams. Ecological Indicators, 84, 573-582. DOI: 10.1016/j. ecolind.2017.09.030.

Cordeiro, J. L. P., \& Hasenack, H. (2009). Cobertura vegetal atual do Rio Grande do Sul. In V. de P., Pillar, S. C. Müller, Z. M. de S. Castilhos, \& A. V. A Jacques (Eds.), Campos sulinos: conservação e uso sustentável da biodiversidade (pp. 285-301). Brasília: Ministério do Meio Ambiente.

Cummins, K. W., \& Klug, M. J. (1979). Feeding ecology of stream invertebrates. Annual Review of Ecological Systems, 10, 147-172.

Dalosto, M., \& Santos, S. (2011). Differences in oxygen consumption and diel activity as adaptations related to microhabitat in Neotropical freshwater decapods (Crustacea). Comparative Biochemistry And Physiology Part A: Molecular \& Integrative Physiology, 160(4), 461-466. DOI: 10.1016/j.cbpa.2011.07.026

Dominguez, E., \& Fernandez, H. (2009). Macroinvertebrados Bentónicos Sudamericanos: Sistemática y Biología. Tucumán: Fundación Miguel Lillo.

Echelpoel, W. V., Forio, M. A. E., Butsel, J. V., Lock, K., Utreras, J. A. D., Dominguez-Granda, L. E., \& Goethals, P. L. M. (2018). Macroinvertebrate functional feeding group structure along an impacted tropical river: The Portoviejo River (Ecuador). Limnologica, 73, 12-19. DOI: 10.1016/j.limno.2018.10.001

Feio, M. J., \& Dolédec, S. (2012). Integration of invertebrate traits into predictive models for indirect assessment of stream functional integrity: A case study in Portugal. Ecological Indicators, 15(1), 236247. DOI: 10.1016/j.ecolind.2011.09.039

Ferreira, A., Cyrino, J. E. P., Duarte-Neto, P. J., \& Martine1li, L. A. (2012). Permeability of riparian forest strips in agricultural, small subtropical watersheds in southeastern Brazil. Marine and Freshwater Research, 63, 1272-1282. DOI: 10.1071/MF12092

Fidelis, L., Nessimian, J. L., \& Hamada, N. (2008). Distribuição espacial de insetos aquáticos em igarapés de pequena ordem na Amazônia Central. Acta Amazônica, 38(1), 127-134. DOI: 10.1590/ S0044-59672008000100014

Fu, L., Jiang, Y., Ding, J., Liu, Q., Peng, Q., \& Kang, M. (2015). Impacts of land use and environmental factors on macroinvertebrate functional feeding groups in the Dongjiang River basin, southeast China. Journal of Freshwater Ecology, 31(1), 21-35. DOI: 10.1080/02705060.2015.1017847

Genner, M. J., Taylor, M. I., Cleary, D. F. R., Hawkins, S. J., Knight, M. G., \& Turner, G. F. (2004). Beta diversity of rock-restricted cichlid fishes in Lake Malawi: importance of environmental and spatial factors. Ecography, 27(5), 601-610.

Guevara, G., Reinoso, G., \& Villa, F. (2005). Estudio del orden Trichoptera en su estado larval en la cuenca del río Coello Departamento del Tolima. Revista de la Asociación Colombiana de Ciencias Biológicas, $17,59-70$.

Hamada, N., Nessimian, J. L., \& Querino, R. B. (2014). Insetos Aquáticos na Amazônia Brasileira: 
taxonomia, biologia e ecologia. Manaus: Editora do INPA.

Harper, D., Mekotova, J., Hulme, S., White, J., \& Hall, J. (1997). Habitat heterogeneity and aquatic invertebrate diversity in floodplain forests. Global Ecology and Biogeography Letters, 6 (3-4), 275-285.

Hawkins, C. P., \& MacMahon, J. A. (1989). Guilds: The multiple meanings of a concept. Annual Review Entomology, 34(1), 423-451. DOI: 10.1146/annurev. en.34.010189.002231

Heino, J. (2009). Biodiversity of aquatic insects: spatial gradients and environmental correlates of assemblage-level measures at large scales. Freshwater Reviews, 2(1), 1-29. DOI: 10.1608/FRJ-2.1.1

Heino, J., Bini, L. M., Karjalainen, S. M., Mykrä, H., Soininen, J., Vieira, L. C. G., \& Diniz Filho, J. A. F. (2010). Geographical patterns of micro-organismal community structure: are diatoms ubiquitously distributed across boreal streams? Oikos, 119, 129-137. DOI: 10.1111/j.1600-0706.2009.17778.x

Heino, J., Muotka, T., \& Paavola, R. (2003). Determinants of macroinvertebrate diversity in headwater streams: regional and local influences. Journal of Animal Ecology, 72, 425-343. DOI: $10.1046 /$ j.1365-2656.2003.00711.x

Hepp, L. U., Landeiro, V. L., \& Melo, A. S. (2012). Experimental Assessment of the Effects of Environmental Factors and Longitudinal Position on Alpha and Beta Diversities of Aquatic Insects in a Neotropical Stream. International Review of Hydrobiology, 97(2), 157-167. DOI: 10.1002/iroh.201111405

Hepp, L. U., \& Santos, S. (2009). Benthic communities of streams related to different land uses in a hydrographic basin in southern Brazil. Environmental Monitoring and Assessment, 157(1-4), 305-318. DOI: 10.1007/s10661-008-0536-7

Hepp, L. U., Urbim, F. M., Tonello, G., Loureiro, R. C., Sausen, T. L., Fornel, R., \& Restello, R. M. (2016). Influence of land-use on structural and functional macroinvertebrate composition communities associated on detritus in Subtropical Atlantic Forest streams. Acta Limnologica Brasiliensia, 28(3). DOI: 10.1590/ S2179-975X0616

Hillebrand, H. (2004). On the generality of the latitudinal diversity gradient. American Naturalist, 163, 192-211.

Hussain, Q. A., \& Pandit, A. K. (2012). Macroinvertebrates in streams: A review of some ecological factors. International Journal of Fisheries and Aquaculture, 4(7), 114-123. DOI: 10.5897/IJFA11.045

Jacobsen, D. (2004). Contrasting patterns in local and zonal family richness of stream invertebrates along anAndean altitudinal gradient. Freshwater Biology, 49(10), 1293-1305. DOI: 10.1111/j.1365-2427.2004.01274.x

Jun, Y., Kim, N., Kwon, S., Han, S., Hwang, I., Park, J., ... Hwang, S. (2011). Effects of land use on benthic macroinvertebrate communities: Comparison of two mountain streams in Korea. Annales de Limnologie International Journal of Limnology, 47, 35-49. DOI: 10.1051/limn/2011018

Júnior, A. P., Conceição, C. S., Lobo, R. R., Santos, C. O R., \& Sardinha, A. S. (2019). Association between ephemeroter, plecoptera and trichoptera and the limnimetric parameters of the water quality index. Brazilian Applied Science Review, 3(2), 839-863.

Magurran, A. E. (2013). Medindo a diversidade biológica. Curitiba: Ed. da UFPR.

McCafferty, W. P. (1981). Aquatic Entomology: The Fishermens and Ecologists Illustrated Guide to Insects and their Relatives. Boston: Jones and Bartlett Publishers.

Melo, A. S. (2009). Explaining dissimilarities in macroinvertebrate assemblages among stream sites using environmental variables. Zoologia, 26(1), 79-84. DOI: $10.1590 / \mathrm{S} 1984-46702009000100013$

Merritt, R. W., \& Cummins, K. W. (2006). An introduction to the aquatic insects of North America ( $3^{\text {rd }}$ ed.). Iowa: Kendall Hunt Publishing.

Merritt, R. W., Cummins, K. W., \& Berg, M. B. (2008). An introduction to the aquatic insects of North America ( $4^{\text {th }}$ ed.). Iowa: Kendall Hunt Publishing.

Merritt, R. W., Fenoglio, S., \& Cummins, K. W. (2016). Promoting a functional macroinvertebrate approach in the biomonitoring of Italian lotic systems. Journal of Limnology, 76, 1s, 5-8. DOI: 10.4081/ jlimnol.2016.1502

Monteiro do Amaral, P. H., De Almeida Gonçalves, E., Da Silveira, L. S., \& Da Gama Alves, R. (2019). Richness and distribution of Ephemeroptera, Plecoptera and Trichoptera in Atlantic forest streams. Acta Oecologica-International Journal of Ecology, 99, 103441. DOI: 10.1016/j.actao.2019.103441

Nakamura, F., \& Kikuchi, S. (1996). Some methodological developments in the analysis of sediment transport processes using age distribution of floodplain deposits. Geomorphology, 16, 139-145. DOI: 10.1016/0169-555X(95)00139-V

Ongaratto, R., Loureiro, R. C., Restello, R. M., \& Hepp, L. U. (2018). Effects of land use and limnological variables on the dissimilarity of common and rare aquatic insects in Atlantic Forest streams. Revista de Biología Tropical, 66(3), 1223-1231. DOI: 10.15517/ RBT.V66I3.30825 
Overbeck, G. E., Müller, S. C., Fidelis, A., Pfadenhauer, J., Pillar, V. D. P., Blanco, C. C.,... Forneck, E. D. (2007). Brazil's neglected biome: The South Brazilian Campos. Perspectives in Plant Ecology, Evolution and Systematics, 9, 101-116.

Overbeck, G. E., Müller, S. C., Fidelis, A., Pfadenhauer, J., Pillar, V. D. P., Blanco, C. C., ... Forneck, E. D. (2009). Os campos sulinos: um bioma negligenciado. In V. D. P. Pillar, S. C. Müller, Z. M. de S. Castilhos, \& A. V. À Jacques (Eds.), Campos sulinos: conservação e uso sustentável da biodiversidade (pp. 26-41). Brasília: Ministério do Meio Ambiente.

Petsch, D. K. (2016). Causes and consequences of biotic homogenization in freshwater ecosystems. Internacional Review Hydrobiology, 101, 113-122. DOI: 10.1002/iroh.201601850

Piedras, S. R. N., Bager, A., Moraes, P. R. R., Isoldi, L. A., Ferreira, O. G. L., \& Heemann, C. (2006). Macroinvertebrados bentônicos como indicadores de qualidade de água na barragem Santa Bárbara, Pelotas, RS, Brasil. Ciência Rural, 36(2), 494-500. DOI: 10.1590/ S0103-84782006000200020

Pillar, V. D. P., Müller, S. D., Castilhos, Z. M. S., \& Jacques, A. V. A. (2009). Campos Sulinos: Conservação e Uso Sustentável da Biodiversidade. Brasília: Ministério do Meio Ambiente.

R Core Team. (2016). RStudio: Integrated Development for $R$. Boston, MA: RStudio, Inc. Retrieved from: http:// www.rstudio.com

Reynoso-Velasco, D., \& Sites, R. W. (2019). Taxonomic overview of the family Naucoridae (Heteroptera: Nepomorpha) in Mexico. Dugesiana, Revista de Entomologia, 26(1), 3-12.

Rezende, R. S., Santos, A. M., Henke-Oliveira, C., \& Gonçalves, J. F. (2014). Effects of spatial and environmental factors on benthic a macroinvertebrate community. Zoologia, 31(5), 426-434. DOI: 10.1590/ S1984-46702014005000001

Rosa, B. J. F. V., Rodrigues, L., Oliveira, G. S., \& Alves, R. G. (2014). Chironomidae and Oligochaeta for water quality evaluation in an urban river in southeastern Brazil. Environmental Monitoring and Assessment, 186(11), 7771-7779. DOI: 10.1007/ s10661-014-3965-5

Santos, S., Bond-Buckup, G., Gonçalves, A. S., Bartholomei-Santos, M. L., Buckup, L., \& Jara, C. G. (2017). Diversity and conservation status of Aegla spp. (Anomura, Aeglidae): an update. Nauplius, The Journal of the Brazilian Crustacean Society, 25, 1-14. DOI: 10.1590/2358-2936e2017011

Santos, J. B. O., Silva, L. H. S., Branco, C. W. C., \& Huszar, V. L. M. (2015). The roles of environmental conditions and geographical distances on the species turnover of the whole phytoplankton and zooplankton communities and their subsets in tropical reservoirs. Hydrobiologia, 764, 171-186. DOI: 10.1007/ s10750-015-2296-Z

Sensolo, D., Hepp, L. U., Decian, V. S., \& Restello, R. M. (2012). Influence of landscape on the assemblages of Chironomidae in Neotropical streams. International Journal of Limnology, 48(4), 391-400. DOI: 10.1051/ $\operatorname{limn} / 2012031$

Souza, L. O. I., Costa, J. M., \& Oldrini, B. B. (2007). Odonata. In Guia on-line: Identificação de larvas de Insetos Aquáticos do Estado de São Paulo. Froehlich, C. G. (org.). Retrieved from http://sites.ffclrp.usp.br/ aguadoce/guiaonline

Tubic, B., Popovic, N. Z., Rakovic, M. J., Petrovic, A. S., Simic, V. M., \& Paunovic, M. M. (2017). Comparison of the effectiveness of kick and sweep hand net and Surber net sampling techniques used for collecting aquatic macroinvertebrate samples. Archives of Biological Sciences, 69(2), 233-238. DOI: 10.2298/ ABS160622087T

Tuomisto, H. (2010). A diversity of beta diversities: straightening up a concept gone awry. Defining beta diversity as a function of alpha and gamma diversity. Ecography, 33, 2-22. DOI: 10.1111/j.1600-0587.2009.05880.x

Utz, R. M., Hilderbrand, R. H., \& Boward, D. M. (2009). Identifying regional differences in threshold responses of aquatic invertebrates to land cover gradients. Ecological Indicators, 9, 556-567. DOI: 10.1016/j. ecolind.2008.08.008

Vannote, R. L., Minshall, G. W., Cummins, K. W. L., Sedell, J. R., \& Cushing, C. E. (1980). The River Continuum Concept. Journal of Fisheries and Aquatic Sciences, 37(1), 130-137. DOI: 10.1139/f80-017

Vásquez-Ramos, J. M., Guevara-Cardona, G., \& ReinosoFlorez, G. (2014). Factores ambientales asociados con la preferencia de hábitat de larvas de tricópteros en cuencas con bosque seco tropical (Tolima, Colombia). Revista de Biologia Tropical, 62, 21-40. DOI: 10.15517/rbt.v62i0.15776

Vieira, M. S., \& Overbeck, G. E. (2015). Recuperação Dos Campos. In V. D. P. Pillar \& O. Lange (Eds.), Os Campos do Sul (pp. 151-152). Porto Alegre: Rede Campos Sulinos - UFRGS.

Vinatier, F., Tixier, P., Duyck, P. F., \& Lescourret, F. (2011). Factors and mechanisms explaining spatial heterogeneity: a review of methods for insect populations. Methods in Ecology and Evolution, 2, 11-22. DOI: 10.1111/j.2041-210X.2010.00059.x 
Wentworth, C. K. (1922). A scale of grade and glass terms for clastic sediments. The Journal of Geology, 30(5), 377-392.

Wheeler, B., \& Torchiano, M. (2016). ImPerm: Permutation Tests for Linear Models (R package version 2.1.0). Retrieved from https://CRAN.R-project.org/ package $=1 \mathrm{mPerm}$

Whiles, M. R., \& Wallace, J. B. (1997). Leaf litter decomposition and macroinvertebrate communities in headwater streams draining pine and hardwood catchments. Hydrobiologia, 353, 107-119.
Worthen, W. B., Gregory, S., Felten, J., \& Hutton, M. J. (2004). Larval habitat associations of Progomphus obscurusat two spatial scales (Odonata: Gomphidae). International Journal of Odonatology, 7(1), 97-109. DOI: $10.1080 / 13887890.2004 .9748199$

Worthen, W. B., \& Horacek, H. J. (2015). The Distribution of Dragonfly Larvae in a South Carolina Stream: Relationships with Sediment Type, Body Size, and the Presence of Other Larvae. Journal of Insect Science, 15(31), 1-7. DOI:10.1093/jisesa/iev01 